\title{
The Students Learning from Home Experience during Covid-19 School Closures Policy in Indonesia
}

\author{
Purniadi Putra 1, Fahrina Yustiasari Liriwati ${ }^{2}$, Tasdin Tahrim ${ }^{3}$, Syafrudin', Suhono ${ }^{4}$, \\ Aslan $^{6 *}$ \\ 1,6 Institut Agama Islam Sultan Muhammad Syafiuddin Sambas, Indonesia \\ 2 STAI Auliaurrasyidin Tembilahan Riau, Indonesia \\ 3 Institut Agama Islam Negeri Palopo, Indonesia \\ 4 STAI Al Haudl Ketapang, Indonesia \\ ${ }^{5}$ Institut Agama Islam Ma'arif NU (IAIMNU) Metro Lampung, Indonesia
}

Corresponding Author: Aslan, aslanmarani88@yahoo.com*

\author{
ARTICLE INFO \\ Article history: \\ Received \\ June 24, 2020 \\ Revised \\ August 12, 2020 \\ Accepted \\ September 01, \\ 2020
}

ABSTRACT

This article analyzed the learning experience of students at home during the school closing period in response to the Covid-19 pandemic in Indonesia. Through this study, an in-depth understanding of the life experiences, perceptions, and motivation of students were obtained from either the school or their parents. These outputs would be input into policy making and solving learning problems towards a new normal era. Now the school closures have been running for almost seven months and it almost about to reopening this mid-August 2020. To understand this phenomenon issue, some data searching have been performed ranging from daily papers, academic journal, and educational related literature. The data search then analyzed under the phenomenological application approach. Compiling the existing data and students voices, this study showed that the students learning experiences during six month learning from home responding the national policy stopping the corona virus spreading can be reported based on 10 websites visited have expressed their best coverage over students learning difficulty and challenge from different perspectives. Most websites mentioned students hardship in learning from home caused the lack of learning resources such not access to internet and parents ability to support their children learning.

Keywords: School Closures Policy In Covid-19, Covid-19, Learning Online

How to cite Putra, P., et al., (2020).The Students Learning from Home Experience during Covid-19 School Closures Policy in Indonesia. Jurnal Iqra' : Kajian Ilmu Pendidikan, 5(2). 30-42. https://doi.org/10.25217/ji.v5i2.1019

Journal Homepage http://journal.iaimnumetrolampung.ac.id/index.php/ji/

This is an open access article under the CC BY SA license https://creativecommons.org/licenses/by-sa/4.0/

Published by Institut Agama Islam Ma'arif NU (IAIMNU) Metro Lampung

\section{INTRODUCTION}

Since November 2019 the world has been shocked by the news of the Covid-19 outbreak confirmed by WHO, an international body that handles human health. This world health institution announced originality of outbreak from the city of Wuhan, China then spreading to more cities before being transmitted to the closest countries with death rates and isolation care for infected cases. So, efforts to prevent the spread the virus by closing public business activities including closing schools have been done immediately. The closures of schools were valid for all levels from schools to universities and immediately followed by several neighboring countries such as 
Taiwan, Korea and Japan (Jung et al., 2020). This situation has raised the world attention as the first time in human history-world policy closes schools in response to preventing the spread of a pandemic (Viner et al., 2020; Wright et al., 2020). Similar concern also come from the Unesco, ince Covid-19 shocked the world at the end of last year, this world education affairs agency estimates that more than 1.3 billion students in schools, colleges and non-formal education institutions have laid off their students to learn with facilities as they are (Wodon, 2020).

In the next development, in January, 2020, UNESCO for Asia and the Pacific confirmed that more Asian countries had become the fastest-spreading region until more new cases were confirmed by the world body for education and culture. As a result, more local and international movements and public business activities are restricted and even some countries close their borders until the unspecified time (Crawford et al., 2020; Seymour-Walsh et al., 2020; Wyres and Taylor, 2020). Two months in March 2020 almost the entire world simultaneously announced the closure of all public business activities including schools and universities and sudden distance learning policy implemented to ensure learning activities could be continued by utilizing virtual learning resources, linking learning from home to home and teachers to teacher. Because the decision to close the school was decided suddenly, it is believed that there will be many challenges and difficulties faced especially students from low socioeconomic family (Lee, 2020; Ghosh et al., 2020; Restubog et al., 2020).

Effectively in mid-March 2020 Covid-19 succeeded in forcing 180 countries to close their schools and universities until an unspecified time as an initiative to slow the spread of the virus that may reduce in casualties due to COVID-19 infection. Furthermore, Azevedo et al. 2020) and Naudé (2020) discovered that until July 2020, around 1.6 billion students were affected as a result of the closure to avoid further exposure to the outbreak. According to UNICEF prediction, there are 134 countries that are still enforcing school closing on a national scale (Gutierrez-Romero, 2020). Therefore, it is undeniable that there are already a number of countries which have now started reopening to schools, but there are still very few numbers. Looking at what Goldstein (2020) finding proved that more students similar to loss a year learning resulting from pandemic disruptions. Logically if the closing school situation continues, then the inequality of learning outcomes due to Covid-19's response continues to widen.

According to Abidah et al. (2020), Darmawan et al. (2020) Wargadinata et al. (2020) the absence of students in the classroom due to the national policy of learning from home for corona virus reasons, this indeed it needs special studies to ascertain whether schools can also be a place to spread viruses such as normal cases of spread in a crowd outside. There should have been more research investigating such problems during school closure to understand how the virus spreads in the school environment. In other words, it is not enough to take in common thoughts how the transmission of the virus among adults (Sintema, 2020; Basilaia and Kvavadze, 2020). So, on that basis, efforts to stop the spread can be used as a reference for further school closures or reopening or can also be a school opening with the application of distance keeping or other prevention methods based on research evidence, no schools in green areas should also follow the instructions of the central government which in fact they are in a red zone, a high category of cases of Covid-19 infection. By doing so there will be no reduction in gaps in nationally learning outcomes. Another study by Viner et al. (2020) found that it is possible that after the Covid-19 response for quite long period, many students will drop out because of the long time spent with their friends in a free 
environment especially those from remote areas who have to work to support their low-income families.

The study on the impact of school and university closures policies has also been carried out in other countries, understanding the voices and experiences of students in such as the heavy pressure resulting from the difficulty of adapting to the changing service procedures of each school and university. Difficulties resulting by requirement, expectations, and uncertainty of each academic demand before the end of the evaluation period. In addition with the condition of students from families who are less able to facilitate children with technological tools has enabled them to participate in the development of learning activities in a distance approach optimally, and a number of questions of technical guidance and supervision of the learning process from their respective homes arises.

Investigating the impact of the spread of the corona virus on learning achievement among Ghanaian students, (Owusu-Fordjour et al. 2020) has suggested the low learning outcomes of students in some school and university were main cause of low learning achievement. The study reviled that more students could have passed their home learning period with lack of facilities and parents supervision. Similarly to most Indonesian families from low economic background who could not effort to learning supports as needed to succeed could be a cause most student's learning hardship from home. This is a reality in many part of school in Indonesia. Ideally, it becomes the national concern that all stake holders to help solve this learning gap among Indonesia students.

Furthermore, related to research conducted by Brown et al. (2020) about understanding student learning experiences confirms that very little news and daily conversation regarding the challenges faced by students affected by Covid-19 on achieving learning outcomes at all levels of education is heard. What are the impacts and difficulties of students in participating fully in individual and collaborative learning using online facilities - students with students and teachers - supported by inadequate technology during school closure. Therefore, this paper related to the 2019 corona virus would be investigated the experiences of students learning from home during the school closure policy implemented from March to July 2020 in Indonesia.

\section{METHODS}

This paper was to give understanding the life experiences of students learning from home in response to national policies to stop the spread of Covid-19. The phenomenological approach was chosen as a practical method of collecting data, completing the analysis process, and reporting results. Smith and Osborn (2020) suggested that this method was used in many qualitative studies because its phenomenological nature can provide an overview of how to understand a person's experiences or events. That way, the researchers explored what the real purpose of the research being carried out is. We conducted a search for headlines of online newspapers and then a critical analysis of the content of these headlines (news, videos, journals, and websites). We conduct searches using keywords such as "student learning experience", "school closure", "COVID-19 pandemic", "distance learning", etc. After collecting the data, the analysis begins by using a phenomenological analysis approach to describe and interpret themes and information relevant to the research question and to find the principles of the validity and reliability of these findings. Similar advice was also put forward by Alase (2017) that phenomenological design was one of the best 
research designs that allows researchers to explore events or life experiences of certain groups to understand them through descriptive and interpretive approaches.

\section{RESULT AND DISCUSSION}

The first findings result from students learning experiences from home in the middle of the Corona Virus pandemic proves how high the education gap is in several places in Indonesia. This is stated by teachers and researchers as student learning when the COVID-19 outbreak. The gap referred to infrastructure and technology constraints so as to increase the emergence of this gap between regions.

"... My sister is sent assignments from teachers every day, the results will be sent back (submit_red) via Gmail. But if her sister doesn't have a lot of homework [from school], at least maybe a week between 2 to 3 tasks...," (Participant\#1).

Searching website of the Voa Indonesia.com edition 21 May 2020 and we found that the widespread corona virus issue at the beginning of 2020 has forced the government to close schools and colleges and expect only home-based learning activities. However, many people questioned this with a very complex reason from the matter of economic ability and the availability of technology that can support students learning. Many people are very concerned about this challenge faced by not only students but parents. Here's is one of expression:

"... how can the teacher only send material through WA [WhatsApp], then students do the best they can and photo them, then send back to the teacher for evaluation. Is our child able to continue to work with other children, this is my problem to question, because I know every student has different abilities..., "(participant\#2).

Our next exploration arrived at a review of the impact of the 2019 corona virus, which is a portrait of learning evaluation through the distance system or "Learning from Home", a study of 4 provinces in Indonesia. As in other countries, the government issued a sudden policy of "learning from home" when the state was in a Covid-19 emergency. However, because it is sudden, automatically it is also very serious impact in the field. Searched from theconversation.com (Gullotta, 2020; Sukoco et al., 2020). The following is an excerpt of his findings:

"... the results of our study found an evaluation of media learning on internet access that was felt quite specifically by students from less financial families and an understanding of the use of online media...." (Participation \# 3).

The next visiting is an online journal publication reporting an analysis of student learning experience from home during campus closure responding to the government policy of stopping the spread of the corona 2019 virus in one of Indonesian universities in early May 2020. The finding revealed that the average students learning experiences categorize very good, although the study finds indications of difficulties and limitations in a whole online learning activities for further evaluation.

"...The results of all of the learning experiences of students at home during the Covid response took place both viewed from the point of enthusiasm, the ability to use technology facilities both for personal and collaborative, online activities with very good results even though there are some difficulties and obstacles..." (participant\#4).

The next searching is that we searched for Suara.com online media and recorded their conversations with several students on the commemoration of National Education Day on May 2, 2020. On this occasion Suara.com covered the experiences of students in both schools and universities where they successfully interviewed several students about various the problematic difficulties they experienced while studying at 
home during the Covid-19 response we searched on https://www.suara.com (Indriani and Efendi, 2020). The following quote:

"... This time the National Education Day was celebrated with a very different nuance, last year it was enlivened with many activities and celebrations. However, this year was celebrated in an atmosphere where specially all students must stay at home while studying online with all means and limited encouragement ... " (participant \# 5).

The next is the Merdeka.com daily edition May 5th, 2020 which reports that the Minister of Education and Culture noted that government has ordered more than 646,200 educational institutions starting from the early education level to the university sends their students to study at home with parents and using online facility. According to educational analyst, this closure due to national policy has impacted on education as a whole. Here is the main headline:

"...The impact of this closure was also felt by the students parents because they had to become teachers' substitutes. This also has the potential to students stress because the average inability of parents to replace the role of school teachers for months. Especially parents who are very busy with their own work outside the home so that everything becomes a problem, " (Participant\#6).

The seventh search found the response of the Minister of Education, Nadiem Makarim, on the challenge of student's distance learning since the 2019 Corona Pandemic virus. According to the minister, through his discussion "Distancing Learning Impacting Students", he said this is a global phenomenon of all countries affected by the plague covered by https://news.detik.com (Chaterine, 2020). He added that distance learning actually requires about 5 years of preparation. However, the reason Covid-19 make students and the community be adaptable and patience.

"... finally we must accept that even in a very challenging transition, it does not mean that we cannot use it as an opportunity to change. So this nation will see the changes coming from students and parents and the community trying to learn by different methods available..." (participant \# 7).

While https:/ / www.bbc.com (Wijaya, 2020) for Indonesia highlights the school's view of students being left behind in the academic achievement of the impact of the deadly epidemic outbreak of the corona virus. While parents view academics as the second choice rather than student safety. However, if the school closures continues for a long time, the students are worried that the academic setback will continue. Here is what was said by one of the school leaders:

"If I ask, students should be activated by the school again as before, what else in this area is not a very severe area like the condition of the red zone area. crowded or other appropriate ways (Participant\#8).

Searching on the website of medcom.id edition 13 April 2020 raised 10 challenges of students learning from their own homes. These ten points are the result of the teachers' conversation during the implementation of school policies from home responding to Covid-19 to medcom staff. According to online media, this happens because of total students learning at home rushed experiences not only surprise students, teachers but also parents. These ten points include internet connection allowing students to connect with other students and teachers in real time, students' readiness to use internet applications and the availability of parents to control learning.

"... these ten challenges really overwhelmed students, teachers and parents. For example, every teacher must stay focused on the application that is shared by every teacher, sometimes not all teachers are able to focus and accurate so that all online learning communities can be 
online to learn with real time. Again not all families have such modern facilities for multiple utility... "(Participant\#9).

The next search is the highlight of the 28 May 2020 edition of the online newspaper Wartakotalive titled technology stuttering among students and teachers is a major challenge experienced since online learning policies since the corona virus outbreak in 2019. This online media also covers the next challenge is the scarcity of internet access let alone internet access students in the area do not have an accessible network. Here is one of the expressions:

"... in addition to the difficulty of internet access, another obstacle is the limited understanding and expertise in using technology by the majority as a means of learning activities for their children online. The most difficult to understand is the limited ability of school educators to have become a problem before the current period as a facility modern century learning..." (participant\#10).

In general, the findings from all of the searched websites have informed many studies about the difficulties students have experienced since learning from home to respond government policy helping stop the spread of Covid-19 nationally. It is undeniable that the findings of this study are very important in helping to support the current educational situation which has been affected by coronavirus. Each web that is sought is on average reported deep concern and information that is all very relevant to the solution to the problems of education in the country in general and the difficulty of students learning from home in particular. In short, what is informed by various web sites sought enables writers to raise educational information in order to answer the main problem of this research with the latest educational developments that mean a significant effort to solve problems when challenging researchers and the general public.

From the searching on the abc.net.au for Indonesia, this online media has provided to some of the content needed by this qualitative study where students' learning challenges as they were sent home to keep learning. This international news online media has delivered their update its news with evidence of how large the gap in the implementation of better education, especially when students are expected to study at home during the school closure policy with the help of infrastructure as it is and proper teacher guidance is rarely far away. This gap occurs among students with various socioeconomic backgrounds. Van Lancker and Parolin (2020) and Brzezinski et al. (2020) results proved that COVID-19 has caused schools to have total closures to the difficulty of students getting their rights in education and welfare equally. Furthermore, this is school closure as a reason for the public policy to stop the epidemic but also has raised the problem of social crisis among students sharply.

Studies on the impact of national policies to combat the spread of the coronavirus 2019 especially the challenge on the educational process have been carried out in many different scopes. We explored the study results of a portrait assessment of student learning from home or a distance system of 4 provinces. After the national policy of students unplanned learning from homes, we find there are quite a lot of problems faced, especially the difficulties faced by students and families who are unable to approach learning in terms of technology based and full time parents mentoring. Purwanto et al. (2020) through exploration studies, they have found how seriously the results of each government policy are made after the students have to learn from home only since the emergence of cases of exposure to the corona virus. This impact arises as students must study with a reliable internet connection solely to those who live in 
areas that do not yet have internet access while parents are busy outside to work as before.

Many Covid-19 related publications have analyzed the learning experience faced students during door school closures in responding to the public protocol of stopping the coronavirus 2019 spreading in many different countries. One of them was done to the University of Sunan Gunung Djati early this year. The finding suggested that more academic communities mainly students said their experiences in quite good category with although with some difficulties and limitations resulting from a whole learning process utilizing enough technology support. This is a little bit different from other voices searched as this investigation was for university students where the learning mood using technology is a normal practice. This similar to Chick et al. (2020) pointed out that learning from home during responding the Covid-19 policy can be done through technological application as the community want to stay well informed with information and education during crisis hit the country. In this regard, the technology is a solution for community learning at large while it might not be applicable for school children without adult supervision (Basilaia and Kvavadze, 2020; Aslan, 2019; Aslan, 2017; Putra et al., 2020; Putra and Aslan, 2020).

The searching on the Suara.com website about their updates on national education commemorative days May 2, 2020. Suara.com had the opportunity to report on student learning experiences at home since high school and college closed has successfully shared their experiences with difficulties and obstacles. What Suara.com reported has similar story as Owusu-Fordjour et al., (2020) remarked that the Covid-19 has challenged more students learning from home without properly supported by online learning facilities and other resources as students normally have in learning from school or university in classroom face to face.

Merdeka.com and (Faqir, 2020) reports about the number of responses that more than 646,200 schools and universities were closed and students were to send home to study with long distance learning system. In addition, various analyses that the national closure has had a major impact on education, especially the difficulties of students who are in remote areas with different socioeconomic conditions. Majority are concern as until now there is no sign of this outbreak is going to end. Related to this disorder, Toquero (2020) identified some difficulties as well as opportunities for education practices during the pandemics of COVID-19 in the Philippine education context with pedagogical approvals. Therefore, this impact is also experienced by many outside school communities due to the difficulties of the guardians of students replacing the role of school teachers. These effects have all actually caused students to be depressed and finally their learning has been dropped, plus more who have been very active outside of the home despite surviving a period of self-isolation.

The last searched website has highlighted the failure of teachers and students as a major factor causing the challenges of learning at home. In addition, according to majority of online media, the challenge was also affected by the scarcity of internet resources, especially those faced by students in remote areas. At the end of this media review also noted that the understanding and ability of parents to operate technology became a source of learning needed by students to learn distance learning. Wang et al. (2020) discovered that mitigating the serious impacts of students learning from home supporting them during the pandemic can be done by parents through using online learning approaches. Therefore, parents' ability to use technology for multiple learning purposes is so supportive efforts. 
As explained earlier, this study wanted to understand the experiences and challenges of students learning from home during the school closure to respond the Covid-19 impact. The policy of closing schools and sending students to study with family supervision, Setiawan (2020), as recommended by the world education agency UNESCO. Although the policy of this world body intends to save students from the dangers of Covid-19, if this continues for a long time, the impact will have a major effect on reducing student learning outcomes. This is very reasonable when referring to the findings of research by Viner et al. (2020) where the school closure and policy practice during the COVID-19 outbreaks have had an impact on the achievement of learning outcomes. However, other studies on the impact besides education must also receive balanced attention, between saving lives from the threat of coronavirus and reducing student education outcomes.

While there are still many issues related to school closure, it needs to be understood where the challenges and difficulties of students are when they have to catch up with learning facilities and supervision that is very minimal when compared to studying at school. For example, during the sending of students studying at home, many students are geographically and economically impossible to learn by distance. This will clearly create huge gap with the condition of children learning who come from families economically and geographically advantageous (Tran et al., 2017). This typical gap is often found in Indonesia's educational environment, both in rural and urban areas.

More literature is in line with the aims of this study have said that the policy of closing schools in an effort to respond to the sudden Covid-19 outbreak certainly left many problems, especially when students had to learn as much as possible only relying on technology or learning in long-distance networks, let alone during the pandemic, which had economic difficulties, prior to that the problem of catch-up innovation technology was still a problem. issues that have no solution at all Murtonen (2018) \& Marston (2020) in particular a study that focuses on what support technology can provide for families who are economically marginalized. However, this study will not add new conflicts between learning outcomes in homes by students from families located with families in the suburbs who are struggling with technological advances and innovative learning. In this study, the author tries to understand what has been mentioned in the initial objectives, namely the effort to understand the various experiences of learning difficulties and challenges of students as long as they are required to study at home.

This study is in accordance with its method, namely reviewing ten websites that have provided various concern on students experienced declared in learning since the Covid-19 Indonesia. Besides, this study also tries to explore the causes of this obstacle experienced and how students and parents are respond to this learning difficulty issue. The results of this study actually do not surprise us with the finding that there are quite a lot of challenges for students when they have to study and stay at home between studying and stay healthy. Reviewing to them that students also experienced with motivation as they have to be home learning not with their peers as they do in school.

As a consequence of these experiences, most students found themselves saving life and learning with conflicting, especially as they have to do school work low support. Azevedo et al. (2020) noted that there are so high potential impacts resulted from the covid-19 to the school closures policy both on school and learn achievement:. Some who have batter support, may do work as required. These students who do not 
get enough support, they just do the work just with whatever it is. Apart from that this study also found that students experiences learning from home dealing with the support given by their school was very low. Most teachers just used simple method to help student learning such as sending and submission work using WhatApps application, this is not as what it has to be the support received from schools. Ideally, the schools may also prepare better support both in lesson and medical support in case any student is need for medical support. For this matter Bayham and Fenichel (2020) finding review that the impact of government policy on school closing to respond the COVID-19 in the health support and care in a modeling research.

We concluded that schools need to realize that closing school policy is not only sent students home to learn while saving life, but also provided better support with more technology and working application where more students may get the support at standard. So that the students, teachers and school may experience this school closures policy a real solution for both learning and stay save from coronavirus treat during pandemic.

This study is about understanding students learning from home experiences during the Covid-19 pandemic through review of ten national newspaper headlines from May to end of June 2020. This qualitative study reviewed ten national newspaper headlines voicing the typical challenges experienced by students and parents as they learned in limited support during the pandemic. Ten participants had voiced their experiences and learning difficulties at home since the government officially enacted a school closure policy, the reason for responding to the coronavirus so that the transmission of COVID-19 can be stopped. Even though the school through the teachers provides support learning services via distance (WhatApps), students and parents feel they are not supported adequately and appear very passive than they should be.

\section{CONCLUSIONS}

This educational related paper is written in order to report a qualitative finding on investigating what students lived challenge after they were sent home to study since outbreaks of Covid-19 in Indonesia. There are a lot studies done understanding the general educational impacted by the Covid-19 pandemic. However, there is no many has done over the typical students experiences from home such as what challenge and difficulty faced. Therefore, to understand this specific problem, there were ten online mass media websites have been visited mainly national based media that have put a serious concern over social and educational impact resulting from the public policy to respond the spreading of coronavirus pandemic among students from schools to university levels. These ten national mass media websites searched have allowed this study to answer the question formulated. The majority websites visited voiced their concern over students lived experiences in learning from home with huge impacts ranging from availability of online learning technology, parents readiness to support learning, student learning management, and government readiness to provide support their sudden national learning policy during pandemic crisis. Therefore, to help the students learning from hardship, there are a number educational issues and improvement shall be done as priority so that the students learning can result better during the school closures period. 


\section{ACKNOWLEDGEMENTS}

Thanks to representatives of national newspaper media including Chaterine from detik.com, Faqir from merdeka.com, Indriani, Efendi from Suara.com, Sukoco, Purba, Arsendy from theconversation.com, and Wijaya, from BBC.com where their articles we have made participants in our study data needs. And finally we thank you for contributing their thoughts, time and energy to help complete our research

\section{AUTHOR CONTRIBUTION STATEMENTS}

All authors had fully taken participation in the research conduction and fully approved the final product of the manuscript writing.

\section{REFERENCES}

Abidah, A., Hidaayatullaah, H.N., Simamora, R.M., Fehabutar, D., Mutakinati, L., 2020. The Impact of Covid-19 to Indonesian Education and Its Relation to the Philosophy of "Merdeka Belajar." Stud. Philos. Sci. Educ. 1, 38-49. https:// doi.org/10.46627/sipose.v1i1.9

Alase, A., 2017. The Interpretative Phenomenological Analysis (IPA): A Guide to a Good Qualitative Research Approach. Int. J. Educ. Lit. Stud. 5, 9-19. https:/ / doi.org/10.7575/aiac.ijels.v.5n.2p.9

Aslan, 2019. Peran Pola Asuh Orangtua di Era Digital. J. Stud. Insania 7, 20-34. http:/ / dx.doi.org/10.18592/jsi.v7i1.2269

Aslan, 2017. Pumping Teacher dalam Tantangan Pendidikan Abad 21. Muallimuna 2, 89-100. http:// dx.doi.org/10.31602/ muallimuna.v2i2.771

Azevedo, De, J.P.W., Hasan, Amer, Goldemberg, Diana, Iqbal, Aroob, S., Geven, Martijn, K., 2020. Simulating the Potential Impacts of COVID-19 School Closures on Schooling and Learning Outcomes: A Set of Global Estimates (English). World Bank 1. Google Scholar

Basilaia, G., Kvavadze, D., 2020. Transition to online education in schools during a SARS-CoV-2 coronavirus (COVID-19) pandemic in Georgia. Pedagog. Res. 5, 19. Google Scholar

Bayham, J., Fenichel, E.P., 2020. Impact of school closures for COVID-19 on the US health-care workforce and net mortality: a modelling study. Lancet Public Health 5, e271-e278. https:/ / doi.org/10.1016/S2468-2667(20)30082-7

Brown, N., Riele, K. te, Shelley, B., Woodroffe, J., 2020. Learning at home during COVID-19: effects on vulnerable young Australians (Report). Peter Underwood Centre for Educational Attainment. Google Scholar

Brzezinski, A., Deiana, G., Kecht, V., Van Dijcke, D., 2020. The covid-19 pandemic: government vs. community action across the united states. Covid Econ. Vetted Real-Time Pap. 7, 115-156. Google Scholar

Chaterine, R.N., 2020. Nadiem Ungkap Tantangan Belajar dari Rumah Akibat Pandemi COVID-19 [WWW Document]. detiknews. URL https:/ / news.detik.com/berita/d-5047242/nadiem-ungkap-tantangan-belajardari-rumah-akibat-pandemi-covid-19 (accessed 7.12.20).

Chick, R.C., Clifton, G.T., Peace, K.M., Propper, B.W., Hale, D.F., Alseidi, A.A., Vreeland, T.J., 2020. Using Technology to Maintain the Education of Residents During the COVID-19 Pandemic. J. Surg. Educ. 77, 729-732. https:/ / doi.org/10.1016/j.jsurg.2020.03.018

Crawford, J., Butler-Henderson, K., Jurgen, R., Malkawi, B.H., Glowatz, M., Burton, R., Magni, P., Lam, S., 2020. COVID-19: 20 countries' higher education intra-period 
digital pedagogy responses. J. Appl. Learn. Teach. 3. https:/ / doi.org/10.37074/jalt.2020.3.1.7

Darmawan, D., Miharja, D., Waluyajati, R.S.R., Isnaeniah, E., 2020. Sikap Keberagamaan Masyarakat Menghadapi Wabah COVID-19. Relig. J. Studi Agama-Agama Dan Lintas Budaya 4, 115-124. Google Scholar

Faqir, A.A., 2020. Kemendikbud Catat 646.200 Sekolah Tutup Akibat Virus Corona [WWW Document]. merdeka.com. URL https://www.merdeka.com/uang/kemendikbud-catat-646200-sekolah-tutupakibat-virus-corona.html (accessed 7.12.20).

Ghosh, R., Dubey, M.J., Chatterjee, S., Dubey, S., 2020. Impact of COVID-19 on children: Special focus on psychosocial aspect. education 31, 34. Google Scholar

Goldstein, D., 2020. Research Shows Students Falling Months Behind During Virus Disruptions. N. Y. Times. Google Scholar

Gullotta, A., 2020. The Conversation: In-depth analysis, research, news and ideas from leading academics and researchers. [WWW Document]. The Conversation. URL https://theconversation.com/uk (accessed 7.12.20).

Gutierrez-Romero, R., 2020. Conflict in Africa during COVID-19: Social Distancing, Food Vulnerability and Welfare Response (SSRN Scholarly Paper No. ID 3616421). Social Science Research Network, Rochester, NY. https:// doi.org/10.2139/ssrn.3616421

Indriani, R., Efendi, D.A., 2020. Hardiknas 2020 di Tengah Pandemi: Ini Curhatan Siswa, Orangtua dan Guru [WWW Document]. suara.com. URL https://www.suara.com/lifestyle/2020/05/02/141500/hardiknas-2020-ditengah-pandemi-ini-curhatan-siswa-orangtua-dan-guru (accessed 7.12.20).

Jung, S., Akhmetzhanov, A.R., Hayashi, K., Linton, N.M., Yang, Y., Yuan, B., Kobayashi, T., Kinoshita, R., Nishiura, H., 2020. Real time estimation of the risk of death from novel coronavirus (2019-nCoV) infection: Inference using exported cases. medRxiv 2020.01.29.20019547. https:/ / doi.org/10.1101/2020.01.29.20019547

Lee, J., 2020. Mental health effects of school closures during COVID-19. Lancet Child Adolesc. Health 4, 421. https:/ / doi.org/10.1016/S2352-4642(20)30109-7

Marston, H.R., 2020. COVID-19 vs Social Isolation: the Impact Technology can have on Communities, Social Connections and Citizens [WWW Document]. URL https://community.geron.org/blogs/hannah-marston/2020/04/10/covid-19vs-social-isolation-the-impact-technology, https://community.geron.org/blogs/hannah-marston/2020/04/10/covid-19vs-social-isolation-the-impact-technology (accessed 8.7.20).

Murtonen, K.-P., 2018. Strengths and limitations of using mobile technology in community based rehabilitation in a resource-poor setting. Google Scholar

Naudé, W., 2020. Entrepreneurial Recovery from COVID-19: Decentralization, Democratization, Demand, Distribution, and Demography.

Owusu-Fordjour, C., Koomson, C.K., Hanson, D., 2020. The impact of covid-19 on learning - the perspective of the ghanaian student. Eur. J. Educ. Stud. 0. https:// doi.org/10.46827/ ejes.v0i0.3000

Purwanto, A., Pramono, R., Asbari, M., Hyun, C.C., Wijayanti, L.M., Putri, R.S., Santoso, priyono B., 2020. Studi Eksploratif Dampak Pandemi COVID-19 Terhadap Proses Pembelajaran Online di Sekolah Dasar. EduPsyCouns J. Educ. Psychol. Couns. 2, 1-12. Google Scholar 
Putra, P., Aslan, 2020. Pengembangan bahan ajar berbasis imtaq dan iptek di era revolusi industri 4.0 pada mata pelajaran sains madrasah ibtidaiyah. TaLimuna J. Pendidik. Islam 9, 1-15. https:/ / doi.org/10.32478/talimuna.v9i1.345

Putra, P., Mizani, H., Basir, A., Muflihin, A., Aslan, A., 2020. The Relevancy on Education Release Revolution 4.0 in Islamic Basic Education Perspective in Indonesia (An Analysis Study of Paulo Freire's Thought). Test Eng. Manag. 83, 10256-10263. Google Scholar

Restubog, S.L.D., Ocampo, A.C.G., Wang, L., 2020. Taking control amidst the chaos: Emotion regulation during the COVID-19 pandemic. Elsevier. https:// doi.org/10.1016/j.jvb.2020.103440

Setiawan, A.R., 2020. Scientific Literacy Worksheets for Distance Learning in the Topic of Coronavirus 2019 (COVID-19). Google Scholar

Seymour-Walsh, A.E., Weber, A., Bell, A., 2020. Pedagogical foundations to online lectures in health professions education. Rural Remote Health 20, 6038-6038. Google Scholar

Sintema, E.J., 2020. Effect of COVID-19 on the Performance of Grade 12 Students: Implications for STEM Education. Eurasia J. Math. Sci. Technol. Educ. 16, em1851. https://doi.org/10.29333/ejmste/7893

Smith, J.A., Osborn, M., 2020. Interpretative Phenomenological Analysis. Qual. Psychol. 28. Google Scholar

Sukoco, G.A., Purba, R.E., Arsendy, S., 2020. Riset dampak COVID-19: potret gap akses online "Belajar dari Rumah" dari 4 provinsi [WWW Document]. The Conversation. URL http://theconversation.com/riset-dampak-covid-19-potretgap-akses-online-belajar-dari-rumah-dari-4-provinsi-136534 (accessed 7.13.20).

Toquero, C.M., 2020. Challenges and Opportunities for Higher Education amid the COVID-19 Pandemic: The Philippine Context. Pedagog. Res. 5. https:// doi.org/10.29333/pr/7947

Tran, H., Abbott, M., Jin Yap, C., 2017. How does working capital management affect the profitability of Vietnamese small- and medium-sized enterprises? J. Small Bus. Enterp. Dev. 24, 2-11. https:/ / doi.org/10.1108/JSBED-05-2016-0070

Van Lancker, W., Parolin, Z., 2020. COVID-19, school closures, and child poverty: a social crisis in the making. Lancet Public Health 5. https:// doi.org/10.1016/S2468-2667(20)30084-0

Viner, R.M., Russell, S.J., Croker, H., Packer, J., Ward, J., Stansfield, C., Mytton, O., Bonell, C., Booy, R., 2020. School closure and management practices during coronavirus outbreaks including COVID-19: a rapid systematic review. Lancet Child Adolesc. Health 4, 397-404. https://doi.org/10.1016/S23524642(20)30095-X

Wang, G., Zhang, Y., Zhao, J., Zhang, J., Jiang, F., 2020. Mitigate the effects of home confinement on children during the COVID-19 outbreak. The Lancet 395, 945947. https:/ / doi.org/10.1016/S0140-6736(20)30547-X

Wargadinata, W., Maimunah, I., Dewi, E., Rofiq, Z., 2020. Student's Responses on Learning in the Early COVID-19 Pandemic. Tadris J. Kegur. Dan Ilmu Tarb. 5, 141-153. Google Scholar

Wijaya, C., 2020. Siswa sekolah "tertinggal" secara akademik karena pandemi, orang tua: "Saya pilih anak selamat." BBC News Indones.

Wodon, Q., 2020. COVID-19 Crisis, Impacts on Catholic Schools, and Potential Responses | Part II: Developing Countries with Focus on Sub-Saharan Africa. COVID-19 Cathol. Sch. Google Scholar 
Wright, A.L., Sonin, K., Driscoll, J., Wilson, J., 2020. Poverty and Economic Dislocation Reduce Compliance with COVID-19 Shelter-in-Place Protocols (SSRN Scholarly Paper No. ID 3573637). Social Science Research Network, Rochester, NY. https:// doi.org/10.2139/ssrn.3573637

Wyres, M., Taylor, N., 2020. Covid-19: using simulation and technology-enhanced learning to negotiate and adapt to the ongoing challenges in UK healthcare education. BMJ Specialist Journals. Google Scholar

\section{Copyright Holder :}

(C) Putra, P., et al., (2020).

First Publication Right :

(C) Jurnal Iqra' : Kajian Ilmu Pendidikan

This article is under:

(ㅇ)(1) 